\title{
Analisis Stilistika Pantun Upacara Adat Perkawinan Melayu Sambas Serta Relevansinya Sebagai Apresiasi Sastra Di SMA
}

\author{
Indriyana Uli ${ }^{1)}$, Lizawati ${ }^{2)}$, Netti Yuniarti ${ }^{3)}$ \\ iyanauli@gmail.com ${ }^{1)}$, lizaucu@gmail.com²), yuniarty.netty@gmail.com ${ }^{3)}$ \\ IKIP PGRI Pontianak, Jalan Ampera, Pontianak ${ }^{123)}$
}

\begin{abstract}
Abstrak. Tujuan dari penelitian ini adalah untuk mendeskripsikan gaya bahasa serta relevansi pantun upacara adat perkawinan Melayu Sambas dalam pembelajaran apresiasi sastra di tingkat SMA. Metode penelitian ini berupa studi dokumenter dengan bentuk penelitian ini adalah deskriptif kualitatif dengan pendekatan stilistika yang memaparkan gaya bahasa dalam pantun upacara adat perkawinan Melayu Sambas memiliki variasi bahasa terlihat dari segi dialeknya. Penggunaan majas dalam pantun juga memberikan nilai estetika dalam rima irama yang akan menghasilkan bunyi yang indah. Gaya bahasa pantun upacara adat perkawinan Melayu Sambas menggungkapkan gambaran kehidupan atau kebiasaan sehari-hari masyarakat Sambas. Adapun gaya bahasanya berupa majas perbandingan, majas pertentangan, majas perulangan, dan majas pertautan. Sedangkan dalam pembelajaran pantun yang terdapat pada kompetensi inti dan kompetensi dasar kurikulum 2013 pada kelas XI semester ganjil SMA. Pantun upacara adat perkawinan Melayu Sambas meningkatkan minat menulis pantun siswa. Siswa lebih aktif menulis teks pantun dengan bahasa dan kebiasaan yang terdapat di daerahnya sendiri.
\end{abstract}

Kata kunci: stilistika, gaya bahasa, relevansi

\section{Pendahuluan}

Salah satu bentuk karya sastra ialah pantun. Pantun merupakan bentuk puisi lama asli Indonesia yang dapat menghibur dan menegur yang diungkapkan melalui perasaan dan pikiran, karena ungkapan tersebut disusun dengan kata-kata hingga sedemikian rupa sehingga sangat menarik untuk dibaca dan didengar. Pantun terdapat hampir di seluruh daerah Indonesia. Kata pantun berasal dari kata patuntun dalam bahasa Minangkabau yang berarti penuntun. Di Tapanuli bernama ende-ende, di Jawa bernama parikan, sedangkan di Sunda bernama sisindiran. Kata pantun mengandung arti misal, seperti dan umpama. Menurut Emzir dan Rahman (2016) mengemukakan bahwa pantun adalah puisi lama yang terikat oleh syarat-syarat tertentu (jumlah baris, jumlah suku kata, kata, persajakan dan isi).

Melalui pantun, seorang dapat menyampaikan pandangannya tentang kehidupan yang ada disekitarnya. Oleh sebab itu, mengapresiasinya berarti berusaha menemukan nilai-nilai kehidupan yang tercermin dalam karya sastra tersebut. Karya sastra menurut ragamnya dibedakan atas prosa, puisi dan drama.

Puisi merupakan bentuk karya sastra yang mengungkapkan pikiran secara imajinatif. Puisi dibedakan menjadi dua yaitu puisi lama dan puisi baru. Puisi lama adalah puisi yang terikat oleh aturan-aturan, salah satunya pantun. Sedangkan puisi baru adalah puisi yang isinya lebih bebas dari pada puisi lama, baik dalam segi jumlah baris, suku kata, maupun rima. Tradisi berpantun merupakan bahasa lisan yang dipakai oleh masyarakat melayu dalam kehidupan sehari-hari untuk berkomunikasi satu sama lain.

Tradisi berpantun masih sangat kental dalam budaya masyarakat Melayu Sambas dan masih menjadi kebanggaan tersendiri bagi masyarakatnya karena pantun juga merupakan tunjuk ajar melayu. Uli, dkk (2016) mengungkapkan bahwa pantun mengandung gaya bahasa yang 
berfungsi memperindah bunyi, menghidupkan atau memperjelas gambaran mengenai suatu hal/perasaan, membangkitkan suasana dan kesan tertentu, serta mengintensifkan makna. Pantun dalam masyarakat Melayu di Sambas merupakan suatu kebiasaan yang selalu dilakukan masyarakatnya. Pantun Melayu Sambas memiliki nilai budaya maupun adat istiadat atau kebiasaan orang-orang Melayu yang gemar berpantun dalam segala tradisi seperti pernikahan, sunatan, tujuh bulanan, menam padi, maupun kegiatan sehari-harinya (Wiguna, dkk. 2017).

Saat ini pantun-memantun masih digunakan dalam berbagai kegiatan. Tradisi ini seharusnya diyakini dan diwarisi oleh sekelompok masyarakat di dalamnya, namun masih ada yang tidak mengikuti adat sehingga terjadilah penyimpangan dan mengakibatkan hal-hal yang tidak diinginkan.

Masyarakat Melayu Sambas mempunyai adat ketika hendak melangsungkan perkawinan. Mereka masih meyakini dan menekuninya rangkaian adat istiadat tersebut. Adat istiadat ini perlu terus dilestarikan guna pelestarian dari keberagaman kebudayaan Indonesia, dengan adanya pelestarian tersebut ragam budaya Indonesia terutama di Kalimantan Barat akan terjaga. Salah satu cara untuk menjaga keberagaman budaya tersebut ialah dengan mengkaji dan memahami nilai-nilai maupun struktur yang ada di dalam Pantun upacara adat perkawinan Melayu Sambas.

Pantun juga menjadi materi dalam pembelajaran bahasa Indonesia di SMA. Pantun masuk dalam pembelajaran yang akan mengapresiasi sastra. Pembelajaran apresiasi sastra merupakan bagian dari pembelajaran bahasa. Pada hakikatnya, pembelajaran sastra adalah membawa siswa ke arah pengalaman sastra. Pengalaman adalah semua yang terjadi dalam hidup manusia dihayati, dinikmati, dirasakan, dipikirkan sehingga dapat lebih berinisiatif (Rokmansyah, 2013). Dengan begitu, sikap resposif dan sensitif diharapkan muncul secara wajar. Siswa menghayati dan menelusuri sendiri setiap karya secara total dan utuh, bukan penghayatan secara intelektual belaka, tetapi unsur afektiflah yang memegang peranan penting.

Hendaknya para remaja khususnya remaja usia sekolah mendapat suatu pembelajaran mengenai apresiasi sastra dari bangku sekolah agar para remaja dapat mengambil pelajaran yang terkandung dari sebuah teks sastra dan tidak menutup kemungkinan mereka dapat menerapkan dalam kehidupan sehari-harinya. Akan tetapi, pembelajaran sastra pada saat ini telah menjadi sebuah pembelajaran yang bermasalah. Masalah tersebut tidak lain pada hasil pembelajaran yang telah dilaksanakan masih bersifat teoretis dan verbalitas. Masih banyak guru yang hanya memberikan para siswanya dengan berbagai macam teori sastra semata. Akibatnya, pengajaran sastra menjadi suatu kegiatan belajar-mengajar yang membosankan. Apalagi genre sastra drama dinilai memiliki pemahaman yang sulit, sehingga minat siswa dalam mempelajarinya sangat rendah.

Pembelajaran apresiasi sastra di sekolah bertujuan agar siswa menikmati dan memanfaatkan karya sastra untuk memperluas wawasan, memperhalus budi pekerti, serta meningkatkan pengetahuan dan kemampuan berbahasa. Selain itu juga agar siswa menghargai dan membanggakan sastra Indonesia sebagai khazanah budaya dan intelektual manusia Indonesia, serta agar siswa memperoleh pengetahuan tentang sastra dengan berbagai teori dan nama pengarang, judul, dan angkatan-angkatannya.

Stilistika digunakan dalam pengkajian Pantun upacara adat perkawinan Melayu Sambas. Stilistika akan mengupas pemakaian gaya bahasa yang khas atau istimewa (Teeuw, 2010). 
Stilistika membicarakan bagaimana memahami dan mengkaji sastra dari segi penggunaan bahasa yang dilakukan oleh penyair. Hal ini dikemukakan oleh Amir (2013) bahwa stilistika sebenarnya merupakan salah satu pendekatan dalam kritik sastra, yaitu kritik sastra yang menggunakan linguistik sebagai dasar kajian. Kajian stilistika ini berkaitan dengan bagaimana kata-kata tersebut menimbulkan efek dan makna tertentu. Analisis stilistika ini merupakan pendekatan struktural, sehingga analisis ini boleh dimulai dari unsur kebahasaan mana pun. Stilistika dalam kaitannya dengan studi retorika haruslah merupakan suatu pencarian filosofis tentang bagaimana kata-kata bekerja atau berpengaruh dalam wacana.

Pantun upacara adat perkawinan Melayu Sambas menjadi objek penelitian ini. Masyarakat Melayu Sambas akan terpengaruh oleh budaya lain jika adat istiadat ini tidak di jaga. Sedikit demi sedikit tradisi berpantun ini akan hilang ditelan zaman dan generasi penerus tidak akan mengenal tradisi berpantun khususnya penggunaan pantun dalam upacara adat perkawinan Melayu Sambas. Oleh karena itu generasi muda terutama lingkungan sekolah haruslah dikawal dan dipandu agar mereka meneruskan dan melestarikan kebudayaan ini dari generasi-generasi yang mendatang. Pantun upacara adat perkawinan Melayu Sambas memiliki daya tarik untuk dipahami, baik dalam bentuk penelitian maupun proses pertunjukannya. Adapun batasan permasalahan dalam penelitian ini yaitu mengenai kajian Stilistika Pantun Upacara Adat Perkawinan Melayu Sambas Serta Relevansinya sebagai Apresiasi Sastra di SMA

\section{Metode}

Metode penelitian ini berupa studi dokumenter dengan analisis jalinan atau mengalir yang meliputi tiga komponen, yaitu reduksi data, sajian data, dan penarikan simpulan. Bentuk penelitian ini adalah deskriptif kualitatif. Penelitian kualitatif ini berdasarkan objek penelitian yang diperoleh dari data penelitian, yaitu Pantun Upacara Adat Perkawinan Melayu Sambas. Pendekatan penelitian yang digunakan dalam penelitian ini adalah stilistika. Stilistika akan mendeskriptif permasalahan gaya bahasa yang terdapat dalam Pantun Upacara Adat Perkawinan Melayu Sambas.

\section{Hasil dan Pembahasan}

Penelitian ini membahas mengenai kajian Stilistika Pantun Upacara Adat Perkawinan Melayu Sambas serta Relevansinya Sebagai Apresiasi Sastra di SMA. Adapun yang menjadi objek penelitian yakni gaya bahasa dan apresiasi sastra di SMA. Peneliti akan memaparkan "Stilistika Pantun Upacara Adat Perkawinan Melayu Sambas serta Relevansinya Sebagai Apresiasi Sastra di SMA", untuk mengetahui gaya bahasa apa saja yang terdapat dalam Pantun Upacara Adat Perkawinan Melayu Sambas dengan menggunakan kajian stilistika. Stilistika akan memaparkan segala hal yang berhubungan dengan gaya bahasa yang menjadi ciri khas bahasa itu sendiri. Sedangkan untuk relevansinya sebagai apresiasi sastra di SMA penelitian ini memaparkan keterkaitan antara kurikulum yang ada di sekolah dengan pembelajaran apresiasi sastra khususnya sastra lama. 


\section{Gaya Bahasa Pantun Upacara Adat Perkawinan Melayu Sambas}

A. Gaya Bahasa Perbandingan

1) Majas Sinekdok (Pras Prototo)

Data [1]

Pelihara burung di dalam peti

Buah kedelai si buah lakom

Pare undangan yang saye hormati

Sebelom dimulai saye ucapkan Assalamu'alaikom

Pada data 1 baris ketiga terdapat majas perbandingan sinekdok (pras prototo). Majas sinekdok (Pras Prototo) tercermin pada kata pare undangan yang saye hormati. Para adalah kata penyerta yang menyatakan pengacuan ke kelompok dan hormati adalah menghargai. Maka Pare undangan yang saye hormati dikatakan majas sinekdok (pras prototo) karena kata para yang mengacu pada undangan yang terkandung pada kata tersebut bukan hanya satu orang yang dihormati melainkan menyebutkan sebagian untuk keseluruhannya. Sehingga kata pare undangan yang saye hormati mengacu pada majas sinekdok (pras prototo).

Data [10]

Taman selasih diatas bukit

Diselimuti embun diwaktu pagi

Terimakasih kami bukan sedikit

Dari ujung rambut sampai ujung kaki

Dalam data 10 bait keempat yaitu "dari ujung rambut hingga ujung kaki” dalam katakata tersebut mengandung majas perbandingan. Kata tersebut termasuk dalam jenis majas perbandingan sinekdoke (totem pro parte). Majas totem pro parte adalah menyebutkan keseluruhan bagian yang menunjuk pada sebagian. Hal ini dibuktikan pada kalimat "dari ujung rambut hingga ujung kaki" yang mengartikan keseluruhan tubuh manusia, akan tetapi kalimat itu hanya menggambarkan sebagian dari keseluruhan tubuh manusia itu yaitu rambut dan kaki, karena manusia dari ujung rambut hingga ujung kaki masih memiliki banyak bagian seperti mata hidung lutut dan lainnya. Menurut kamus besar Bahasa Indonesia arti dari ujung rambut adalah bagian penghabisan dari bulu yang tumbuh pada kulit manusia, terutama kepala. Arti dari ujung kaki menurut kamus besar Bahasa Indonesia adalah bagian penghabisan dari anggota badan yang menopang tubuh dan dipakai berjalan.

Jadi penggalan kata "dari ujung rambut hingga ujung kaki” termasuk kedalam majas sinekdoke (totem pro parte) karena kata ini menyebutkan keseluruhan bagian yang merujuk pada sebagian yaitu tubuh manusia yang digambarkan dari ujung rambut hingga ujung kaki.

Data [11]

Daun pegage dibawah rumah

Pohon kerakap ditepi perigi

Kalaupun ada keluarga kami yang salah 
Kami mohon maaf setulus hati

Dalam data 11 bait ke empat yaitu "kalaupun ada keluarga kami yang salah" termasuk kedalam jenis majas atau gaya bahasa perbandingan, dan termasuk kedalam jenis perbandingan Sineskdoke (pars pro toto). (pars pro toto) adalah majas yang menyebutkan sebagian hal untuk menyatakan keseluruhan. Hal ini dibuktikan pada kata keluarga kami yang menggantikan sekelompok orang yang diwakilkan oleh 1 orang penutur. Arti kata kami menurut kamus besar bahasa Indonesia adalah yang berbicara dengan orang lain, yang menulis atas nama kelompok. Sedangkan arti dari keluarga menurut kamus bahasa Indonesia adalah ibu dan bapak beserta anak-anaknya seisi rumah.

Jadi dalam kata di atas yaitu kata keluarga kami termasuk ke dalam jenis majas perbandingan sinekdoke (totem pars toto) karena kata keluarga kami menggambarkan sebagian hal untuk menyatakan keseluruhan.

2) Majas Personifikasi

Data [5]

Layang-layang jato' di sawah

Surya raye turon ke dunie

Dengan mengucap kata Bismillah

Barang antaran kami terime

Pada data 5 baris kedua terdapat majas perbandingan personifikasi. Majas personifikasi tercermin pada kata Surya raye turon ke dunia. Surya adalah matahari yang bersinar dan dunie adalah dunia bumi dengan segala sesuatu yang terdapat di atasnya. Maka Surya raye turon ke dunia dikatakan majas personifikasi karena kata surya mengacu kepada sifat manusia seolaholah surya bisa turun seperti layaknya perbuatan manusia.

Data [12]

Daon kassum dimasak oleh teh Algi

Kan laok makan tangah hari beganding

Tisanyum-sanyum matehari pagi

Meliat penganten dudok besanding

Pada data 12 baris ke tiga terdapat gaya bahasa perbandingan personifikasi. Gaya bahasa perbandingan personifikasi tercermin pada kalimat "tisanyum-sanyum matehari pagi". Tersenyum adalah memberikan senyuman, tertawa dengan tidak bersuara. Matahari adalah titik pusat tata surya berupa bola berisi gas yang mendatangkan terang dan panas pada bumi pada siang hari. Maka, kata tisanyum-sanyum matehari pagi dikatakan majas personifikasi karena kata matahari mengacu kepada sifat manusia seolah-olah bisa tersenyum layaknya perbuatan manusia sehingga dapat dikatakan bahwa tisanyum-sanyum matehari pagi merupakan majas personifikasi. 
3) Majas Perumpamaan

Data [4]

Merpati terbang bagaikan puan

Ambil kertas lalu dikoyakkan

Barang antaran kame' serahkan

Tolong di terima' dan dipergunekan

Pada data 4 baris pertama terdapat gaya majas perbandingan perumpamaan. Majas perumpamaan tercermin pada kata Merpati terbang bagaikan puan. Merpati adalah seekor burung termasuk bangsa seperti tekukur, perkutut dalam kepercayaan dan kebudayaan melambangkan perdamaian. Sedangkan puan adalah empuan atau perempuan. Maka Merpati terbang bagaikan puan dikatakan majas perumpamaan karena kata merpati yang menggambarkan keindahan burung yang terbang layaknya sifat perempuan. Sehingga kata Merpati terbang bagaikan puan mengacu pada majas perumpamaan.

Data [13]

Pak polisi memakai topi

Untuk menangkap orang berjudi

Bagai sepak sirih penutup janji

Kami terima dengan senang hati

Dalam data 13 bait ketiga yaitu "bagai sepak sirih penutup janji" kata ini termasuk kedalam majas perbandingan perumpamaan. Perumpamaan adalah gaya bahasa perbandingan yang pada hakikatnya membandingkan dua hal yang berlainan dan yang dengan sengaja kita anggap sama. Hal ini dibuktikan dalam kata "bagai sepak sirih penutup janji" yang pada dasarnya telah menjelaskan suatu perumpamaan satu hal dengan hal lainnya. Menurut Kamus Besar Bahasa Indonesia sirih adalah tumbuhan merambat dipohon lain, daunnya berasa agak pedas, biasa dikunyah bersama pinang, kapur, gambir sebagai makanan yang mencandu, penguat gigi dan sebagainya. Sedangkan arti dari penutup menurut kamus besar Bahasa Indonesia adalah pengunci. Jadi kata "bagai sepak sirih penutup janji" merupakan majas perbandingan perumpamaan karena di dalam kata tersebut terdapat kata perumpamaan atau kata perbandingan yaitu "bagai".

4) Majas Pleonesme

Data [14]

\section{Besarnya kapal dari yahudi \\ Sarat bermuat sibayang padi \\ Besar hajat saya diutus datang kemari \\ Untuk menunaikan ikrar dan janji}

Pada data 14 bagian bait ke empat yaitu "untuk menunaikan ikrar dan janji" dalam kata tersebut mengandung majas perbandingan Pleonasme. Pleonasme adalah semacam acuan yang 
mempergunakan kata-kata lebih banyak dari pada yang diperlukan untuk menyatakan satu gagasan atau pikiran. Apabila kata yang berlebihan tersebut dihilangkan maka tidak mengubah makna atau arti. Hal ini dibuktikan dalam kata ikrar dan janji, kata ikrar dan janji ini memiliki arti yang hampir sama, menurut kamus besar Bahasa Indonesia arti ikrar adalah janji yang sungguh-sungguh, sedangkan arti janji adalah ucapan yang menyatakan kesediaan dan kesanggupan untuk berbuat.

Jadi kata "ikrar" dan "janji" di atas termasuk majas perbandingan pleonisme karena dalam kata tersebut menggunakan kata yang lebih banyak dari pada yang digunakan, padahal memiliki arti atau makna yang sama untuk menyatakan suatu gagasan atau pikiran.

5) Metafora

Data [15]

Ke Teluk Keramat dangan Apid

Bawak buah tangan jumpe imam

Rajin-rajinlah sholat di masjid

Tapi usah dolok nak jadi imam

Pada data 15 pada baris ke dua terdapat gaya bahasa perbandingan metafora. Gaya bahasa perbandingan metafora tercantum pada kata buah tangan. Buah artinya bagian tumbuhan yang berasal dari putik biasanya berbiji dan kata tangan artinya anggota badan dari siku sampai ujung jari atau dari pergelangan sampai ujung jari, sedangkan kata buah tangan dalam bahasa Indonesia adalah barang yang dibawa dari bepergian, oleh-oleh. Maka, kata buah tangan dikatakan gaya bahasa perbandingan metafora karena kata buah tangan menggunakan kata atau frase yang memiliki makna kiasan untuk menyamakan atau membandingkan suatu objek dengan objek lainnya, sehingga dapat dikatakan bahwa kata buah tangan merupakan majas metafora.

Data [16]

Mak Inang paggi ke pakkan

Balli buah tangan daan bawak tas

Sireh pinang kamek sarahkan

Mohon diterimak dangan ikhlas

Pada data 16 baris ke dua terdapat gaya bahasa perbandingan metafora. Gaya bahasa perbandingan metafora tercermin pada kata "balli buah tangan daan bawak tas". Buah adalah bagian tumbuhan yang berasal dari bunga atau putik (biasanya berbiji), tangan artinya adalah anggota tangan dari siku sampai ke ujung jari atau dari pergelangan sampai ke ujung jari, sedangkan kata buah tangan artinya adalah barang yang dibawa dari hasil bepergian atau oleholeh. Maka, kata buah tangan dikategorikan dalam gaya bahasa perbandingan metafora karena kata buah tangan menggunakan kata atau frase yang memiliki makna kiasan untuk menyamakan atau membandingkan suatu objek dengan objek lainnya sehingga dapat dikatakan bahwa kata buah tangan merupakan majas metafora. 
B. Gaya Bahasa Pertentangan

1) Majas Paradoks

Data [1]

Pelihara burung di dalam peti

Buah kedelai si buah lakom

Para undangan yang saye hormati

Sebelom dimulai saye ucapkan Assalamu'alaikom

Pada data 1 baris pertama terdapat majas pertentangan paradoks. Majas paradoks tercermin pada kata Pelihara burung di dalam peti. Pelihara adalah jaga atau rawat dan Peti adalah kotak yang tertutup dari kayu atau logam. Maka pelihara burung di dalam peti dikatakan majas paradoks karena kata pelihara pada burung yang seolah-olah bisa dijaga atau dirawat pada kotak yang tertutup yang mengandung pertentangan antara pernyataan dengan fakta yang ada. Sehingga kata Pelihara burung dalam peti mengacu pada majas paradoks.

Data [17]

Taman selasih diatas bukit

Diselimuti embun diwaktu pagi

Terimakasih kami bukan sedikit

Dari ujung rambut sampai ujung kaki

Dalam data 17 bait kedua yaitu "diselimuti embun di waktu pagi" dalam kata tersebut mengandung majas pertentangan paradoks. Majas paradoks adalah majas yang mengandung pertentangan antara pernyataan dan fakta yang ada. Hal ini dibuktikan dalam kata diselimuti embun di mana kata diselimuti pada dasarnya mengarah kepada kegiatan manusia menutupi tubuhnya dengan kain agar hangat atau tidak merasa kedinginan. Dalam kalimat ini kata diselimuti embun berlawanan dengan fakta yang ada sebab embun bukanlah alat atau barang yang dapat dijadikan pelindung tubuh. Menurut kamus besar Bahasa Indonesia selimut artinya adalah kain penutup tubuh, terutama dipakai di waktu tidur, sedangkan arti embun menurut kamus besar Bahasa Indonesia adalah titik-titik air yang jatuh dari udara.

Jadi kata Diselimuti embun di waktu pagi termasuk kedalam jenis majas pertentangan paradoks karena di kalimat tersebut menggambarkan hal yang bertentangan dengan fakta yang ada, yaitu kata diselimuti embun.

Data [7]

Pohon pisang becabang dua

Anak rusa terkena panah

Kalo' pasangan nak idop bahagia

Jangan lupakan ibadah dan sedekah 
Pada data 7 baris pertama terdapat majas pertentangan paradoks. Majas paradoks tercermin pada kata Pohon pisang becabang dua. Pisang adalah tanaman yang buahnya berdaging dan dapat dimakan. Bercabang adalah bagian batang kayu yang tumbuh dibagian batang atau dahan. Maka pohon pisang becabang dua dikatakan majas paradoks karena kata pisang mengandung pertentangan antara pernyataan dengan fakta yang ada, seolah-olah pohon pisang dapat bercabang menjadi dua. Sehingga kata Pohon pisang becabang dua mengacu pada majas paradoks.

C. Gaya Bahasa Perulangan

1) Majas Antanaklasis

Data [1]

Pelihara burung di dalam peti

Buah kedelai si buah lakom

Para undangan yang saye hormati

Sebelom dimulai saye ucapkan Assalamu'alaikom

Pada data 1 baris kedua terdapat majas perulangan antanaklasis. Majas antanaklasis tercermin pada kata buah kedelai si buah lakom. Buah kedelai adalah tumbuhan kacangkacangan yang berbuah kecil-kecil. Buah lakom adalah tumbuhan semak yang merambat. Maka kata buah kedelai si buah lakom dikatakan majas antanaklasis karena ada pengulangan kata buah yang sama namun memiliki makna yang berbeda. Sehingga kata buah kedelai si buah lakom mengacu pada majas antanaklasis.

2) Anafora

Data [18]

Daon nipah di Rambaian

Daon keladi dalam talam

Kalau nikah dah dilaksanekan

Usah lupak dengan rukun Islam

Pada data 18 pada baris ke satu dan dua terdapat gaya bahasa perulangan anafora. Gaya bahasa perulangan anafora tercantum pada kata "daon nipah di rambaian, daon keladi dalam talam". Kata daon dalam bahasa Indonesia adalah bagian tanaman yang tumbuh berhelai-helai pada ranting (biasanya hijau) sebagai alat bernapas dan mengolah zat makanan. Maka, kata daun dikatakan gaya bahasa perulangan anafora karena pada pantun tersebut terjadi perulangan kata pertama pada baris kesatu dan kedua yaitu kata daun, sehingga kata daun merupakan gaya bahasa perulangan anafora.

3) Anadiplosis

Data [19]

Dimane nak ambek sarai 


\section{Ambek sarai di pok ume}

Karap-karaplah magek pak labai

Sanang nak belajar ilmu agame

Pada data 19 pada baris ke satu dan dua terdapat gaya bahasa perulangan anadiplosis. Gaya bahasa perulangan anadiplosis tercantum pada kata "Dimane nak ambek sarai, Ambek sarai di pok ume". Serai dalam bahasa Indonesia adalah tanaman tahunan, membentuk rumpun yang padat, batangnya kaku dan pendek, bentuk daunnya seperti pita yang meruncing ke ujung, menghasilkan minyak serai, bonggol batang yang muda digunakan sebagai penyedap berbagai masakan. Maka, kata serai dikategorikan dalam majas anadiplosis karena kata serai terdapat di akhir kalimat dan digunakan di awal kalimat berikutnya sehingga kata serai termasuk dalam majas anadiplosis.

Data [20]

Bukan batang sembarang batang

Batang dibuang karne rapongan

Bukan datang sembarang datang

Kamek datang dangan rombongan

Pada data dua baris ke tiga dan empat terdapat gaya bahasa perulangan anadiplosis. Gaya bahasa anadiplosis tercermin pada kalimat "Bukan batang sembarang batang, batang dibuang karne rapongan ". Batang adalah bagian tumbuhan yang berada di atas tanah, tempat tumbuhnya cabang dan ranting. Maka, kata batang termasuk ke dalam majas anadiplosis karena kata batang berada diakhir kalimat dan digunakan menjadi kata pertama dalam kalimat berikutnya,sehingga pantun tersebut dikategorikan sebagai gaya bahasa anadiplosis.

4) Mesodilopsis

Data [21]

Paggi ke pasar membeli ikan

Diselalukan membeli handuk

Kalau, ... udah kamek sarahkan

Nambah sudah jumlah penduduk

Pada data empat pada baris ke satu dan dua terdapat perulangan mesodilopsis. Gaya bahasa perulangan mesodilopsis tercantum pada kata "pagi ke pasar membeli ikan, diselalukan membeli handuk". Membeli adalah memperoleh sesuatu melalui penukaran (pembayaran) dengan uang. Maka, kata membeli termasuk dalam gaya bahasa perulangan mesodilopsis karena kata tersebut terjadi perulangan kata atau frase di tengah-tengah baris atau beberapa kalimat berurutan sehingga kata membeli merupakan gaya bahasa perulangan mesodilopsis.

5) Asonasi

Data [23]

Indriyana Uli, Lizawati, dan Netti Yuniarti: Analisis Stilistika Pantun Upacara Adat Perkawinan Melayu Sambas Serta Relevansinya Sebagai Apresiasi Sastra Di SMA 


\section{Buk Mislah carek appan \\ Nak ngulai asam pakai tapoan \\ Dangan bismillah kamek ucapkan \\ Untok memulai pembicaraan}

Pada data 23 baris ke satu, dua, tiga, dan empat terdapat gaya bahasa perulangan asonansi. Gaya bahasa perulangan asonansi tercermin pada kata "Buk Mislah carek appan, nak ngulai asam pakai tappoan, dangan bismillah kamek ucapkan, untok memulai pembicaraan". Maka, kata appan, tapoan, ucapkan, dan pembicaraan dikatakan gaya bahasa perulangan asonansi karena ada penggunaan bunyi vokal dan konsonan yang berulang-ulang di akhir kalimat yaitu huruf a dan n, sehingga kata tersebut merupakan gaya bahasa perulangan asonansi.

D. Gaya Bahasa Pertautan

1) Majas Epitet

Data [22]

Sang raje menunggang kude

Piring kace kebelah due

Kalo' nak idop bahagie

Banyak berdo'e dan berusahe

Pada data 22 baris pertama terdapat majas pertautan epitet. Majas epitet tercermin pada kata sang raje menunggang kude. Sang adalah kata yang dipakai di depan nama orang, binatang atau benda yang dianggap hidup atau di muliakan dan raje adalah penguasa tertinggi pada suatu kerajaan. Maka kata sang raje menunggang kude dikatakan majas epitet karena kata sang mengandung acuan menyatakan suatu sifat mulia untuk seseorang yaitu seorang raja penguasa tertinggi suatu kerajaan. Sehingga kata sang raje menunggang kude mengacu pada majas epitet.

\section{Relevansi Pantun Upacara Adat Perkawinan Melayu Sambas terhadap pembelajaran apresiasi sastra di SMA.}

Apresiasi terhadap karya sastra sangat perlu dan penting guna menunjang atau sebagai koreksian untuk menciptakan suatu hasil karya sastra yang lebih baik lagi. Apresiasi sastra berarti penghargaan, penilaian, dan pengertian terhadap karya sastra, baik yang berbentuk puisi maupun prosa atau suatu kegiatan menggauli sastra dengan sungguh-sungguh hingga tumbuh pengertian, penghargaan, kepekaan pikiran kritis, dan kepekaan perasaan yang baik terhadap cipta sastra. Penghargaan terhadap karya sastra bisa berupa reward sedangkan pemahaman merupakan jalan untuk suatu karya sastra diapresiasi.

Apresiasi sastra dalam pembelajaran di SMA merupakan pembelajaran yang penting dalam menanggapi sastra yang menjadi ciri khas budaya Indonesia. Pembelajaran tersebut tentunya menjadi kurikulum pembelajaran di sekolah. Apresiasi sastra tidak hanya berupa memberikan penilaian atau pertimbangan dalam sebuah karya. Apresiasi juga dapat berupa pembelajaran mengkaji lebih sebuah karya. Kajian tersebut dapat berupa mengenal struktur maupun gaya bahasanya. 
Pembelajaran menulis pantun Kurikulum 2013 dapat menjadi wadah dalam apresiasi sastra terutama puisi lama yakni Pantun Upacara Adat Perkawinan Melayu Sambas yang kaya akan makna dan memiliki ciri khas dari segi gaya bahasanya. Perpaduan antara bahasa Melayu dengan dialek Sambas.

Pantun Upacara Adat Perkawinan Melayu Sambas dapat menjadi sumber ajar dalam pembelajaran pantun di kelas, hal tersebut di tuturkan oleh ibu Erna, S.Pd guru pengajar bahasa Indonesia di SMA Pancasila Kab. Kubu Raya. Ibu erna juga menuturkan dengan pembelajaran pantun terutama pantun Upacara Adat Perkawinan Melayu Sambas siswa dapat mengenal kebudayaan masyarakat Melayu Sambas dalam kegiatan upacara adat perkawinannya. Siswa juga akhirnya merespon dengan memberikan tanggapan positif dan membandingkan pantun yang ada dalam upacara adat masyarakat sekitarnya yang rata-rata bersuku Melayu Pontianak. Dengan adanya pantun Upacara Adat Perkawinan Melayu Sambas dalam pembelajaran pantun di kelas siswa mengungkapkan rasa bangganya akan kebudayaan yang mereka miliki.

Pembelajaran pantun di SMA pada kurikulum 2013 terdapat pada kelas XI semester ganjil dengan komponen berikut:

Tabel 1

Kompetensi Inti dan Kompetensi dasar Pembelajaran Pantun

\section{KOMPETENSI INTI}

3. Memahami, menganalisis menerapkan, pengetahuan faktual, konseptual, prosedural, dan metakognitif berdasarkan rasa ingin tahunya tentang ilmu pengetahuan, teknologi, seni, budaya, dan humaniora dengan wawasan kemanusiaan, kebangsaan, kenegaraan, dan peradaban terkait penyebab fenomena dan kejadian, serta menerapkan pengetahuan prosedural pada bidang kajian yang spesifik sesuai dengan bakat dan minatnya untuk memecahkan masalah

1. Mengolah, menalar, dan menyaji dalam ranah konkret dan ranah abstrak terkait dengan pengembangan dari yang dipelajarinya di sekolah secara mandiri, bertindak secara efektif dan kreatif, serta mampu menggunakan metode sesuai kaidah keilmuan

\section{KOMPETENSI DASAR}

3.1 Memahami struktur dan kaidah teks cerita pendek, pantun, cerita ulang, eksplanasi kompleks, dan film/drama baik melalui lisan maupun tulisan

3.2 Membandingkan teks cerita pendek, pantun, cerita ulang, eksplanasi kompleks, dan film/drama baik melalui lisan maupun tulisan

3.3 Menganalisis teks cerita pendek, pantun, cerita ulang, eksplanasi kompleks, dan film/drama baik melalui lisan maupun tulisan 3.4 Mengevaluasi teks cerita pendek, pantun, cerita ulang, eksplanasi kompleks, dan film/drama berdasarkan kaidah-kaidah teks baik melalui lisan maupun tulisan

4.1 Menginterpretasi makna teks cerita pendek, pantun, cerita ulang, eksplanasi kompleks, dan film/drama baik secara lisan maupun tulisan 4.2 Memproduksi teks cerita pendek, pantun, cerita ulang, eksplanasi kompleks, dan film/drama yang koheren sesuai dengan karakteristik teks yang akan dibuat baik secara lisan maupun tulisan

4.3 Menyunting teks cerita pendek, pantun, cerita 
ulang, eksplanasi kompleks, dan film/drama sesuai dengan struktur dan kaidah teks baik secara lisan maupun tulisan

4.4 Mengabstraksi teks cerita pendek, pantun, cerita ulang, eksplanasi kompleks, dan film/drama baik secara lisan maupun tulisan

4.5 Mengonversi teks cerita pendek, pantun, cerita ulang, eksplanasi kompleks, dan film/drama kedalam bentuk yang lain sesuai dengan struktur dan kaidah teks baik secara lisan maupun tulisan

Kurikulum 2013 dapat menjadi sumber penanaman pendidikan karakter cinta tanah Indonesia dengan mengaplikasikan kekayaan lokal seperti pantun Upacara Adat Perkawinan Melayu Sambas dalam pembelajaran di sekolah khususnya di SMA kelas XI. Pembelajaran tersebut dapat menggali apresiasi diri siswa. Apresiasi yang diberikan siswa tentunya akan berkaitan dengan karakter kepribadiannya. Hal tersebut sejalan dengan informan yang mengungkapkan bahwa pembelajaran apresiasi pantun memiliki peran penting terhadap cinta tanah air. Siswa menjadi paham akan ciri khas budaya Sambas dan gaya bahasa masyarakat Sambas.

\section{Simpulan}

Berdasarkan temuan gaya bahasa pada pantun upacara adat perkawinan Melayu Sambas memiliki keunikan sendiri dengan perpaduan antara bahasa Melayu dengan dialek Sambas. Gaya bahasa pantun upacara adat perkawinan Melayu Sambas bersifat subyektif yang berisikan majas. Terdapat empat majas dalam gaya bahasa yang terdapat dalam pantun melayu tersebut, yaitu majas bahasa perbandingan, majas bahasa pertentangan, majas bahasa perulangan, dan majas bahasa pertautan. Majas-majas tersebut mengungkapkan gambaran kehidupan atau kebiasaan sehari-hari masyarakat Sambas. Majas dalam gaya bahasa pantun upacara adat perkawinan Melayu Sambas juga memiliki variasi bahasa yang berbeda baik dari segi dialek, dan fungsi dari penggunaan majas tersebut. Fungsi majas dalam pantun upacara adat perkawinan Melayu Sambas juga digunakan sebagai estetika dalam rima irama yang akan menghasilkan bunyi yang indah. Fungsi selanjutnya juga untuk memberikan gambaran mengenai perasaan yang akan membangkitkan suasana pendengarnya.

Adapun relevansi pantun upacara adat perkawinan Melayu Sambas tergambar dalam kompetensi inti dan kompetensi dasar kurikulum 2013 pada kelas XI semester ganjil SMA. Pembelajaran Bahasa Indonesia dalam Kurikulum 2013 adalah pembelajaran berbasis teks. Dalam pembelajaran Bahasa berbasis teks, Bahasa Indonesia diajarkan bukan sekadar sebagai pengetahuan bahasa, melainkan sebagai teks yang mengemban fungsi untuk menjadi sumber aktualisasi diri penggunanya pada konteks sosial-budaya akademis.Pembelajaran menulis pantun Kurikulum 2013 memiliki struktur teks pantun. pantun upacara adat perkawinan Melayu Sambas memiliki relevansi dalam pembelajaran apresiasi sastra di SMA khususnya kelas XI semester ganjil. Siswa dapat memahami struktur dan gaya bahasa pantun upacara adat perkawinan 
Melayu Sambas. Selain itu berdasarkan pernyataan informan adanya pembelajaran pantun yang dikaitkan dengan pantun milik masyarakatnya akan menimbulkan rasa menghargai dan lebih mencintai daerahnya sendiri.

\section{Ucapan Terima Kasih}

Peneliti menyampaikan ucapan terima kasih kepada Lembaga Penelitian dan Pengabdian Kepada Masyarakat IKIP PGRI Pontianak selaku pemberi sponsor sehingga penelitian ini dapat dilakukan dan akan terlaksana secara penuh. Ucapan terima kasih juga disampaikan kepada SMP Pancasila Kabupaten Kubu Raya, Informan, dan tim redaksi Jurnal Deiksis atas saran dan masukan untuk perbaikan penulisan artikel ini.

\section{Daftar Pustaka}

Amir, A. (2013). Sastra Lisan Indonesia. Yogyakarta: Cv Andi Offset.

Emzir \& Rahman, S. (2016). Teori dan Pengajaran Sastra. Jakarta: Rajawali.

Rokmansyah, A. (2013). Studi dan Pengkajian Sastra Perkenalan Awal Terhadap Ilmu Sastra. Semarang: Graha Ilmu.

Teeuw. (2010). Sastra dan Ilmu Sastra: Pengantar Teori Sastra. Jakarta: Dunia Pusat Jaya.

Uli, Indriyana., Dkk. 2016. Analisis Gaya Bahasa Pada Lirik Lagu Daerah Pontianak dan Pemanfaatannya sebagai Bahan Pembelajaran Apresiasi Puisi Di SMA. Jurnal Pendidikan Bahasa, 5(1), 100-105.

Wiguna, Zikri., Dkk. 2017. Analisis Nilai-Nilai Pendidikan dalam Pantun Melayu Sambas. Jurnal Pendidikan Bahasa, 6(1), 114-129. 